International Journal of Linguistics, Literature and Culture
Available online at https://sloap.org/journals/index.php/ijllc/
Vol. 6, No. 4, July 2020, pages: 49-61
$\begin{aligned} & \text { ISSN: 2455-8028 } \\ & \text { https://doi.org/10.21744/ijllc.v6n4.905 }\end{aligned}$

\title{
Deconstructing the Evolving Roles of English Language Educators in the 21st Century
}

Joseph Anthony Narciso Z. Tiangco ${ }^{\text {a }}$

Article history:

Submitted: 18 April 2020

Accepted: 09 May 2020

\section{Keywords:}

deconstruction;

English language teaching;

sustainable development;

teachers' roles;

university social responsibility

(USR);

\section{Corresponding author:}

Joseph Anthony Narciso Z. Tiangco,

Department of Applied Foreign Languages,

Shu-Te University, Taiwan.

Email address: tiangcoj@stu.edu.tw

\begin{abstract}
The English language is lingua franca, and although perceived as the global language of modernity and success, its viral spread has inadvertently created marginalizing socioeconomic inequalities. This position paper argues that English language educators in higher education should take a more active role in promoting and implementing University Social Responsibility (USR) programs. English teachers need not limit their focus on language teaching and cross-cultural communication but, at the same time, take on other roles aimed at addressing the needs of the marginalized.
\end{abstract}

International journal of linguistics, literature and culture () 2020.

This is an open access article under the CC BY-NC-ND license.

Peer-review under responsibility of International Association for

Technology, Education and Language Studies (IATELS) (https://creativecommons.org/licenses/by-nc-nd/4.0/).

${ }^{a}$ Department of Applied Foreign Languages, Shu-Te University, Taiwan 


\title{
1 Introduction
}

\begin{abstract}
"It was the best of times, it was the worst of times, it was the age of wisdom, it was the age of foolishness, it was the epoch of belief, it was the epoch of incredulity, it was the season of Light, it was the season of Darkness, it was the spring of hope, it was the winter of despair, we had everything before us, we had nothing before us, we were all going direct to Heaven, we were all going direct the other way - in short, the period was so far like the present period, that some of its noisiest authorities insisted on its being received, for good or for evil, in the superlative degree of comparison only."
\end{abstract}

Charles Dickens (1859)

A Tale of Two Cities

It is the best of times, and it is the worst of times, it is the spring of hope and winter of despair, for English Language Teaching (ELT) and learning in the 21st century. On the one hand, there is so much to appreciate and celebrate given the theoretical, conceptual, and methodological developments in the field that have resulted in various frameworks for professional educators and English Language Learners (ELL) to use as references in either for work or study. Not to mention, advancements in Information and Communications Technology (ICT) have all significantly contributed to the explosion of knowledge content, the creative development of learning applications and teaching-learning strategies, and increased efficiency in disseminating information to masses of learners through video sharing platforms such as YouTube to more organized course programs such as Massive Open Online Courses (MOOCs). Not to mention, free English learning web resources and gamified e-learning and mobile applications abound. There is just a wealth of resources and content knowledge readily available. The ease of owning and using computers and smart devices has made it undeniably possible to access this wealth of resources related to English language learning. Yet, as we talk about studying English in the 21st century as the best of times and as a season of both light and hope, our current period is likewise marked by contradictions. Has the world indeed become a better place for everyone? Regardless of age, sex, gender, race, social-economic status, citizenship, and religion, are the developments mentioned above experienced by learners all over the world? Has English as the world's lingua franca made genuine interconnectedness possible enough to break down borders and perhaps, unnoticed social divides? Or, has it instead only reinforced the privilege of some groups at the expense of others?

Undeniably, technological advancements and the growing number of evidence-based approaches in both teaching and learning have all contributed to the scientific progress of English studies. This position paper argues that there are, nevertheless, overlooked disparities occurring in ELT that have social, cultural, and economic implications on marginalized sectors of modern society. Arguably, higher education should never lose sight of its leadership role as an institution that promotes and strengthens the development of social responsibility programs (UNESCO 1998a, UNESCO 1998b). It would be fallible to think that tasks related to University Social Responsibility (USR) are only for administrators or specially designated social responsibility offices on campus (Gómez, Pujols, Alvarado, \& Vargas, 2018).

The first part of the paper contextualizes the range of issues arising from what Krashen (2003) observed as English fever. What exactly is the English fever, and how has it contributed to a variety of marginalizing issues (social, cultural, educational, and economic) among communities of English language learners? Around two decades ago, the pronouncement of an English fever was a hotly debated topic. Through the years, the fever had become pandemic resulting in the English language becoming lingua franca. The dominant status of the English language as a world language should be good news. Unfortunately, there are unanticipated side effects that have further contributed to disparities that have always previously existed between those who have access to quality educational resources and those who do not. The second part challenges ELT professionals to step out of their comfort zone as educator-intellectuals. This position paper argues for the urgency to deconstruct how English language educators, especially those in higher education, perceive their current roles and responsibilities in teaching the English language. Can ELT professionals have a more sustainable impact on the development of their students other than the simplistic teaching of the English language? 


\section{The World's Lingua Franca: The English Language}

It was during a conference in Taiwan when Krashen (2003) described the English fever as an obsessive motivation and aspiration to learn and acquire English as a second language among people who speak a different mother tongue. Children learned English through after-school programs and other extra-curricular activities out of dissatisfaction with the regular English language programs offered by schools. Already burdened with so much from their daily school workload, children had to invest additional time and effort in studying English. Even English teachers themselves experienced unjust circumstances. There were instances of a marginalizing preference for native Englishspeaking teachers over their nonnative counterparts. A contestable perception prevails among some learners that a native English-speaker is the most ideal and suitable teacher because of having grown up in an English-speaking environment and, at times even, for being white-skinned and having blue eyes. These are some of the symptoms associated with English fever. Why exactly is the English language so pandemic?

Kachru's (1982) Three Concentric Circles Model provides insight into the pandemic. The model discusses the spread and development of world Englishes based on the movement and transplantation of the English language to different parts of the world through migration, colonization, geopolitics, commerce, education, and mass media (see Kachru, Kachru, \& Nelson, 2006). From the USA, UK, Canada, Australia, and New Zealand, the English language has spread to different parts of the world. These are the inner-circle countries where the English language originated. Outer Circle and Expanding Circle countries have welcomed not only the English language per se, but its economic, political and diplomatic, sociocultural, and educational byproducts. Both outer and expanding circles show the hegemonic spread of English as the world's lingua franca. Outer Circle countries such as the Philippines, Hong Kong, Malaysia, India, Puerto Rico, and Nigeria are some examples of directly colonized former territories of either the US or UK. Thus, the transplantation of English was planned and systematic. Colonial subjugation, as a systematic scheme, was best achieved by subtly manipulating the consciousness of the people (Kachru \& Webster, 2015).

Of particular interest are countries in the Expanding Circle. For instance, the predicament of Taiwan and China is quite impressive. It highlights the reach and impact of the English language even though they were never a former colony or territory of the Inner Circle. The following discussions aim to contextualize this further.

Liu (2002) boldly asserted that English language learning was a national obsession in Taiwan. The number of Taiwanese overwhelmingly seeking out English language education for themselves and their children eventually increased throughout the years (see Chang, 2007; Chang, 2008; Chen, 2003; Lin \& Bayram, 2016; Oladejo, 2006;). Recently, Taiwan's National Development Council (2018) released guidelines on how Taiwan will soon officially become a bilingual nation by 2030 (English and Chinese Mandarin). From the initial pronouncement of an English fever in 2002 and after almost two decades, Taiwan's mandate to become a bilingual nation demonstrates the influence of English on the country's national consciousness and its continuous effort at both social-cultural and educational engineering.

Another example is the steady increase in the number of English language learners in the People's Republic of China (PRC) (see Adamson, 2004; Feng, 2005; Feng, 2011; Kachru 1982, 1983). Feng (2011) argues that English language learning is an integral aspect of China's education system. Wei and Su (2012) estimated that around 390.16 million had learned English as a foreign language. As of 2020, China's estimated population is at 1,394,015,977 (The World Factbook, 2020). Although it has been rather difficult to get updated and accurate statistics regarding the exact number of English language learners, the Programme for International Student Assessment in 2018 identifies China as one of the world's top performers in reading, mathematics, and science (OECD, 2019). Unofficial and perhaps unreliable estimates on the Internet places the number of people in China who speak English from 10 to 400 million (see Bolton, 2008; Bolton, 2012; Smith, 2017). Education First (2019) ranks China 40th in the English Proficiency Index with a score of 53.44 (Moderate Proficiency) out of 100 sampled countries from different geographical regions. It ranks 8th out of 25 Asian countries (see Education First, 2019).

Taiwan and China exemplify the fruition of Kachru's (1982) hypothesis regarding the Expanding Circle of world Englishes, especially in consideration of their historical past and geographic distance from Inner Circle countries. Other Expanding Circle countries include Japan, South Korea, Thailand, Indonesia, Vietnam, Myanmar (Burma), Cambodia, and Laos. The English language learning hype is evident as well in each of the countries above (Hock, 2019; Kirkpatrick, Subhan, \& Walkinshaw, 2016). The term English Fever once again re-surfaced when Kim (2015) used it to describe the English language learning craze in South Korea. For brevity, discussions are limited within the

Tiangco, J. A. N. Z. (2020). Deconstructing the evolving roles of English language educators in the 21 st century. International Journal of Linguistics, Literature and Culture, 6(4), 49-61. https://doi.org/10.21744/ijllc.v6n4.905 
Asian context only. The Expanding Circle includes Russia, particular countries in Europe, South America, the Middle East, and Africa that were not former colonies of either the US or UK.

The English language is the world's lingua franca. English language learning is pandemic, and it reached this status fueled by the impact of globalization on societies and cultures around the world (Phillipson, 2001). Socialcultural, economic, political, and diplomatic interconnectedness catalyzed its proliferation. Is it a bad thing that the English language had achieved viral and global status?

Coleman (2011) and McCormick (2017) argue that data trends in the past decades support the conclusion that a relationship exists between thriving globalized economies and the use of English as lingua franca. For instance, the transformation of both Taiwan and China from being once an agriculture-based economy into manufacturing, electronics, and a high technology hub fueled export growth and further economic development as guided by robust national economic planning (Lin \& Wong, 2016). Globalization interconnected the economies of both Taiwan and China with each other and the rest of the world (Meltzer, 2014). Alongside this was the role of English in equipping and empowering human capital. The English language was a tool for economic progress. Government and private sector corporate leaders and workforces proficient in English played an important role in internationalizing the economies of both Taiwan and China. Not only did both countries participate in the global market, but they have also successfully thrived as well despite the 2008 World Financial Crisis. Apple Inc., Adidas, Nike, Proctor \& Gamble, Walmart, and Mercedes Benz are just a few of the many world-renowned multinational brands that have a manufacturing plant in China (Blanchard, 2007). Likewise, semiconductors and electronic chips manufactured in Taiwan are in mobile phones, televisions, computers, and media devices found all over the world (Lin \& Wong, 2016).

\subsection{The Paradox of English as the Language of Success}

English as the world's lingua franca benefits the globalization of world economies through the strengthening of international trade and commerce (Wong \& Dubey-Jhaveri, 2015). Interconnectedness is evident at different fronts as people across the world can communicate and understand each other using English as their common global language.

Many learn the English language driven by its appeal as their underlying motivation. Ultimately, benefits trickle down among those who successfully attain high English proficiency. Financial and economic benefits such as higher wages, career development, travel, and training await highly motivated and diligent English learners. Secondarily, awareness of membership in the global village eventually leads to active participation and assimilation of crosscultural experiences unhindered by any language barrier. It reflects the conscious adoption of a modernized and globalized lifestyle as a member of the global village.

There is no doubt that English proficiency in the four skills (speaking, listening, reading, and writing) opens economic opportunities and the likelihood of substantial financial gains, especially if the skill set matches the needs of a for-profit organization that values internationalization. Besides, there is a tendency to judge modernity, social class, and good education based on English proficiency. Favorable social perceptions of people are associated with how fluent they are in communicating in English. However, Johnson (2009) argues that despite being a tool for economic progress, English language learning is, at the same time, a creator of new inequalities. It is a paradox. Perhaps unintended, but precariously real. The perplexing and unfortunate irony of the new millennium is that no matter how much development there is among national economies in different parts of the world, poverty and various inequalities persist, insidiously contributing to the stratification and marginalization of groups of people. In some instances, direct oppression is even apparent such as instances of abusive outbursts against Syrian, Mexican, and Asian immigrants in the US who are not able to speak English or those who can speak English but just prefer to use their native tongue when speaking to family members even in public places (Miller, 2018). Racism has always been a contentious issue in the US and some other parts of the world (Causadias \& Korous, 2019). It would be unfair to point the blame on the English language since the world has always been imperfect in the first place. Globalization itself is imperfect, but it would be hard to conceive of 21 st-century modernity without the interconnectedness that characterizes the world today.

The paradox of English as the language of modernity and success is that it has unintentionally created or contributed to inequalities (Jayadeva, 2019). English is a tool for social-cultural and economic mobility. More so, it undeniably is a commodity (Johnson, 2009). Hence, those who have access to and can afford the monetary and other costs (time, psycho-emotional, interpersonal, opportunity) associated with English language learning seize the opportunities presented to them. There is enough available literature to conclude that some form of success awaits 
those who persist in their English language learning (Kirkpatrick, Subhan, \& Walkinshaw, 2016; Jayadeva, 2019; Wong \& Dubey-Jhaveri, 2015). What happens to the others who are not so lucky or privileged? They are the unfortunate ones who land somewhere in the continuum of the success-failure dichotomy, marginalized, may it be unintentionally or otherwise.

Inequalities and class struggles have always been there, but modernity has somehow amplified these predicaments. The English language has contributed to and even amplified a range of dichotomies. For instance, there will always be a divide between public and private education, especially within the macrocosm of the government's budget allocation and spending on national education and the perceived importance of a national English language curriculum (Jayadeva, 2019; Rowe \& Perry, 2019). A divide also exists between urban and rural schools (Nguyen, Linh, Quynh, \& Nguyen, 2014). The racial and ethnic demographics of the students, political affiliations, safety, and security issues are all essential and yet, divisive considerations (Chzhen, Rees, Gromada, Cuesta, \& Bruckauf, 2018).

Most importantly, the socioeconomic status of families influences a variety of factors that affect their ability to provide supplemental and after school educational programs and resources to their children. The United Nations Children's Fund (UNICEF) observes that even in the world's wealthiest countries, children's poor scholastic performance is a result of underlying socioeconomic disadvantages (Chzhen et al., 2018). These circumstances raise the pervasive issue of educational inequalities, which are a global problem. Somewhere down the road, the children who were a product of a variety of educational inequalities become high school students who are screened for college admission and even into a particular academic program that they want. For years now, English proficiency has been a significant criterion in higher education admission (AL-Khalil, 2015). Successful students go on to highly reputable schools and programs and have better access to government subsidies, scholarships, and other selfdevelopment funds (Schmid, 2018). In the continuum of the success-failure dichotomy, those students who do not find immediate success settle for whatever opportunities and paths available. As this familiar story goes, students who continue with their English language learning journey do so in improving their proficiency in hopes of landing better career opportunities in the future. The scenarios of success and failure extend well into a lifetime of career development. In each step of the way, English proficiency will partly be a basis of judgment and reason for being either rewarded or marginalized.

On the one hand, it will unlock succeeding opportunities for further success. On the other hand, it will result in either temporary or permanent setbacks. It is almost cyclic that parents who have achieved a certain level of success and have experienced the benefits of English language learning in their lives would demand much from their children. The unsuccessful will most likely brush aside the relevance of English language learning as mere hype. Or, they might obsess in pushing their children to study English to compensate for their shortcomings and inadequacies such as in the case of the English fever. Unfortunately, EFL students' burnout is a relevant issue to confront, as it results in low efficiency and mental health problems (Wang, Wu, \& Ma, 2018). The quality of school and parental support and all other factors, as mentioned earlier, are likely to influence the cycle of success and failure. These are some of the predicaments that lead to the reality of socioeconomic inequalities, dichotomies, and demarcations.

Seemingly, problems and issues plague the world. It is important to reiterate that this paper is not pinning the blame on English language learning, globalization, internationalization, westernization, and colonization. It is cliché to conclude that everyone is to blame for the ills happening all over the world. Still, this paper does argue that now is not the time to be a by-stander. Even though the systematic problems might be perceived as beyond many, inaction only results in apathy, which in return further widens the gap against the marginalized and oppressed.

\section{Deconstructing the Evolving Roles of English Language Educators}

\subsection{Roles and expectations of English language teachers in higher education}

How do these circumstances impact English language teachers, especially in higher education? The fact is, in the hearts of most English teachers, there is a yearning for the success of their students (Ellis, 1980; Ellis, 1999). Regardless of which level, educators generally desire that students achieve their dreams and aspirations (Ellis, 1987; Mart, 2013; Schmid, 2018). Success entails students being able to grow in their English proficiency for whatever end purpose they see its use. It also includes seeing students grow into productive and responsible members of society and the global village.

Tiangco, J. A. N. Z. (2020). Deconstructing the evolving roles of English language educators in the 21 st century. International Journal of Linguistics, Literature and Culture, 6(4), 49-61. https://doi.org/10.21744/ijllc.v6n4.905 
In higher education, the university is a repository of academic knowledge. It is a place meant for cultivating intellectual life in preparation for students' vocational or career prospects. Higher education is a place where students can, through specialized academic and other training programs, sharpen a variety of skills and competencies to equip themselves to become highly employable shortly soon. The success of higher education as an institution correlates with its capacity to successfully prepare the needed human capital for today and even tomorrow's market economy.

Hence, one of the primary roles of higher education professionals is to be an educator who ensures that students receive the best training and preparation needed so that they can achieve success in their chosen field of profession. In this regard, English language educators in higher education preoccupy themselves with teaching, learning, and assessment. They make sure that students prepare themselves in achieving the expected English proficiency prescribed by the system. To be an educator includes other roles such as being a mentor, facilitator, learner, manager, evaluator, assessor, and controller which are all generally considered as necessary in English language education (see Ellis, 1980; Ellis, 1997; Nunan, 1999; Nunan \& Lamb, 1996; Yasmin \& Islam, 2018). Consensus exists that the roles above characterize the modern paradigms of student-centered English language teaching (Archana \& Rani, 2016; Nunan, 1999). Choudhury (2011) argues that the role of innovator is indispensable. The traditional English classroom has become less relevant amidst developments in Information Communications Technology and new approaches in student-teacher interactions. Therefore, creating an innovative learning environment is a challenge that English language educators continuously face.

Ja (2017) mentions resources, participant, and counselor to the list of roles. An expectation is that English language educators provide a variety of resources aimed at enriching learning. With the wealth of knowledge available because of internet technology, English language educators are expected to have screened the multitude of available information and take on the role of students' curator of resources (Archana \& Rani, 2016). Doing so shifts the emphasis away from the English teacher as the only authoritative source of knowledge. It helps students navigate their way around different information sources. Also, Ja (2017) discussed the role of a participant in the teachinglearning process, implying that English language educators actively engage and not just merely observe classroom activities.

Interestingly, Ja (2017) added the role of a counselor based on research results indicating how students' issues interfere with their learning. Burnout among EFL students is a real concern (Wang, Wu, \& Ma, 2018). English teachers should not be surprised to encounter students seeking some form of counseling regarding their personal, family, or relationship issues. If not dealt with appropriately, EFL students are likely to be unmotivated in studying. Matsumoto and Cumming (2018) studied the impact of students' perceptions of English teachers as motivators. Students who show enthusiasm in studying English do so under the influence of a teacher who values motivational factors to learning. Although English teachers may lack the professional training to provide counseling services to students, this should not stop them from listening to and encouraging students to seek out help. As motivators, English teachers provide reassurance of help not only in matters related to English language learning. The roles mentioned above are some of the most commonly identified apart from directly teaching English language acquisition. It is necessary to point out that the identified roles are student-centered, meaning English teachers portray the roles in service of the students whom they regularly teach.

The next required tasks higher education professionals regularly immerse themselves in are research, project management activities, and administration. In this connection, the roles of an intellectual-academic, researcher, project manager, and administrator come to mind. Research productivity equates to being on top of the game for many in higher education. This productivity is characterized and judged by the quality and volume of research output. The clamor for research productivity, unfortunately, operates on the publish or perish principle, which is more challenging for nonnative English-speaking ELT professionals compared to their native English-speaking counterparts (Kung, 2018). Alongside being a researcher is a higher education professional's role as an intellectualacademic. Intellectual discourse through professorial lectures, discussions with likeminded colleagues and students, and time-off for both reading and writing all contribute to a stimulating environment needed by higher education professionals.

Furthermore, higher education professionals are engaged in various industry cooperation projects and administrative work. Funding opportunities abound in higher education wherein professors can apply for grants and work on government-funded projects. Specific industries, corporations, and organizations similarly fund projects of interest to them. Higher education professionals busy themselves in the conceptualization, implementation, and evaluation of various projects and activities. 
Table 1 outlines the different roles of English language educators adapted from Archana and Rani (2016), Choudhury (2011), Ellis (1980, 1997), Ja (2017), Matsumoto, and Cumming (2018), and Nunan (1999). It summarizes the descriptions for each of the previously discussed roles.

Table 1

Roles of English language educators in higher education

\begin{tabular}{|c|c|}
\hline Educator & Involves providing direct instruction or teaching concerning a subject matter. \\
\hline Mentor & $\begin{array}{l}\text { Provides advice or guidance to younger, less experienced persons in the areas of } \\
\text { professional development. }\end{array}$ \\
\hline Facilitator & $\begin{array}{l}\text { It makes the learning process easier to follow and comprehend by shifting one's status } \\
\text { from an authority figure to a neutral guide in carrying out task-based learning } \\
\text { activities. }\end{array}$ \\
\hline Learner & $\begin{array}{l}\text { A person who is learning about a subject or skill. A teacher taking on the role of } \\
\text { learner acknowledges the fact that he or she is learning as well. }\end{array}$ \\
\hline Manager & $\begin{array}{l}\text { Controls and manages a group, organization, activity, or series of activities in carrying } \\
\text { out set goals and objectives. }\end{array}$ \\
\hline Evaluator & $\begin{array}{l}\text { Provides constructive judgment and feedback regarding the quality of a performance or } \\
\text { output meant to show English proficiency. The goal is to compare current evaluations } \\
\text { with set ideal performances or output. }\end{array}$ \\
\hline Assessor & $\begin{array}{l}\text { Develops, calculates, and measures specific or target behaviors to standards or criteria } \\
\text { of English proficiency. Doing so provides measurable feedback regarding the } \\
\text { performance of target behaviors. }\end{array}$ \\
\hline Controller & $\begin{array}{l}\text { Ensures that classroom processes and rules of engagement are appropriately carried out } \\
\text { by students. }\end{array}$ \\
\hline Innovator & $\begin{array}{l}\text { Introduces new ways or approaches to doing things that are experimental or challenges } \\
\text { traditional methods or ideas. }\end{array}$ \\
\hline Resources & $\begin{array}{l}\text { Collects knowledge or information from different sources and organizes them to be } \\
\text { used effectively. }\end{array}$ \\
\hline Participant & $\begin{array}{l}\text { Someone who takes part or is engaged in an activity or process to model or } \\
\text { demonstrate particular behaviors or outputs. }\end{array}$ \\
\hline Counselor & Listens and provides advice or emotional support to persons who need it. \\
\hline Motivator & Promotes and cultivates enthusiasm or positivity for English language learning. \\
\hline Intellectual-Academic & $\begin{array}{l}\text { Engages in reflection and thinking about academic or subject-related issues. Also } \\
\text { involved in stimulating discussions and presentations. }\end{array}$ \\
\hline Researcher & Develops, implements, and writes research papers for publication or presentation. \\
\hline Project Manager & $\begin{array}{l}\text { Develops, implements, and evaluates projects relevant to one's research agenda, } \\
\text { university, or relevant industry partnerships. }\end{array}$ \\
\hline Administrator & Manages processes and persons that are part of a larger group or organization. \\
\hline
\end{tabular}

The roles listed in Table 1 show that English language educators do not only focus on language teaching alone but the holistic development of the learners. Educators invest much time in cultivating students inside and outside the classroom. Whether it is teaching, research productivity, or academia-industry cooperation, the aspiration is always towards success. Ultimately, English language educators desire for the success of their students. The success of students with high English proficiency ultimately reflects the teachers for their practical teaching approaches. It is not surprising why English proficiency test scores are used as a quick basis in concluding successful English language acquisition. To this extent, students' test scores serve as a basis for promoting or reprimanding teachers. Those in power use test scores as a basis in judging the overall success of a particular school or district and in deciding whether or not to reward or cut subsidies and funding.

Moreover, successful research productivity and industry cooperation at one level are testimonies of English language educators' contributions to the advancement of knowledge and its practical applications. Higher education professionals devote much needed time to data-gathering and the often solitary process of research writing. The publish or perish principle has, in many ways, impacted the fast rate at which academics produce research papers.

Tiangco, J. A. N. Z. (2020). Deconstructing the evolving roles of English language educators in the 21 st century. International Journal of Linguistics, Literature and Culture, 6(4), 49-61. https://doi.org/10.21744/ijllc.v6n4.905 
Those familiar with this predicament and understand the struggles of writing can attest to how difficult it is to produce a single research paper. Research writing is time-consuming. Likewise, the planning, implementation, and evaluation of academia-industry cooperation projects are equally tedious processes. In many instances, higher education professionals exert more effort in doing research and industry projects in comparison to the time they set aside for teaching and mentoring students. Note that educators, just like other professionals, have their selves and families that also keep them preoccupied. Higher education professionals are undoubtedly very busy and productive persons. Still, how do the activities of higher education professionals address or lessen the socioeconomic inequalities previously discussed?

\subsection{Deconstruction as a New Consciousness: A Proposal}

Community service often is the approach higher education professionals undertake in addressing socioeconomic inequalities and other social issues. It is charitable work for them, given their available time. In a way, it is the guiltminimizing effort after having already devoted much time to teaching, research, and other administrative projects and activities. In other words, community service tantamount to whatever leftover time and energy are available once all work, and even personal priorities are out of the way. Roles and tasks in higher education simply are prioritized in this manner. It is its culture, a reality that many professors contend with unless one is genuinely a social advocate or, for a long time, been involved in cause-oriented programs and activities.

In some cases, it is paid lip service to the idea that an institution has University Social Responsibility (USR) programs in place. This position paper argues that higher education, as a collective unit, ought to re-commit to the role of not only preparing generations of employable workforces driven by success. Instead, to actively be a catalyst for transformative change in all societies wherein systems are put into place, ensuring that it is part of the mission and vision statement of higher education institutions.

There is nothing wrong with learner-centered teaching and the pursuit of various research and industry projects other than being self-serving. It is self-serving in the sense that the learner-centered or student-centered perspective tends to place privileged students on a pedestal. Unfortunately, student/learner-centeredness, as an educational perspective, has brought about a sense of entitlement among millennials and generation z learners. Entitlement is a concern in higher education (Lippmann, Bulanda, \& Wagenaar, 2009). Segrist, Bartels, and Nordstrom (2018) observe, the rise in classroom incivilities correlates with the growing number of college students' perception of such behaviors as the social norm. It is erroneous to generalize, but it is a real concern among more and more college teachers that students nowadays are different from before. Lythcott-Haims (2015) argues that college students are acting less like adults, and the lack of a sense of maturity is alarming.

As previously discussed, not all students who are studying English have access to the same privileges. Entitled students tend to see and prioritize themselves only. Their success equates to the effort they exert and with the help of teachers taking up the roles of educator, mentor, facilitator, innovator, and motivator. These students perceive the narrow path of their successes, failing to realize that their privileged status has given them an edge for better opportunities. There is a danger to this narrative that exists in the consciousness of privileged and entitled students. They fail to see the oppositional reality of underprivileged students who lack access to mentors, resources, and motivators. They tend to see only their reality of having studied in a reputable school without realizing that some other students are marginalized simply because of the school they are studying in and its geographical location in a rural area. As another example, some students pride themselves with high English proficiency who are indifferent to others because of their broken English and heavy accent. The privileged and entitled tend to perceive the plight of others as none of their concern. By doing or saying nothing, English language educators contribute to the problem of inequality and marginalization. Apathy is and will always be the biggest threat. It allows oppressive narratives to spread and perpetuate themselves like a harmful virus. Deconstructing the privileges and the entitlement of the status quo is necessary, and English teachers have an indispensable role in this process of undoing (Crowley, 1989).

It is perhaps unrealistic to expect that English language educators in higher education can change the world. Inaction and indifference allow marginalizing narratives to spread and persist. Contrarily, purposive action is like getting a vaccination. Joseph (2017) argues that there is nothing wrong with educating the status quo that it is possible to achieve success without being self-serving. To address the needs and injustices against the marginalized is in itself to be successful. The deconstructive analysis of self-serving narratives of success with regards to English language learning is a transformative remedy. To differ and defer, search for a meaningful narrative with a more fitting end purpose that gives the marginalized and oppressed a voice to speak out against the indifference created by entitlement is empowering (Crowley, 1989). By evolving new narratives, and challenging old ones, the roles of 
English language educators in higher education all remain relevant and responsive to the challenges of the times. More importantly, it is vigilance against being deliberate agents that contribute further to inequalities and oppression (Joseph, 2017). English language educators in higher education need to accept that they are at the frontline of proactive vigilance.

Summarized in Table 1 are social constructions of the roles of English language educators that are arguably selfserving only if they solely value the success of privileged and entitled students, the teachers themselves, and the prestige of organizations and the universities. Note, to be a higher education professional in an institution of higher learning is in itself, a form of privilege compared to other sectors of an education system.

Inequalities that plague the 21 st century have resulted in different kinds of socioeconomic, gender, racial, education, and other gaps. It is impossible to eradicate most of the world's problems, but it does not mean that there are no viable solutions. As a new consciousness, the ethos of deconstruction acknowledges that dualistic polarities co-exist. Success co-exists with failure. Students who can afford higher education are financially capable or even wealthy because finishing any 4-year degree program comes with a price tag. On the other side of the dualistic opposites are poor students who often struggle with tuition payments and work part-time jobs. There are affluent private and public schools that co-exist with their less privileged counterparts. Some girls have access to education. Meanwhile, others do not. The irony of deconstruction lies in its acknowledgment of 'it is' and 'it is not' as coexisting phenomena as a philosophical standpoint (Crowley, 1989). Dualistic opposites are brought into awareness and made to shift in balance for whatever purpose through deconstructive analysis. In other words, English language educators in higher education work with the status quo, and the reality of their profession exist students who belong to a categorized opposite about this status quo.

The first step in this deconstructive new consciousness is an awareness of the interrelationship between the status quo and 'others' and how they have been created and marginalized through the systematic development of English language learning. The deconstruction of previously discussed roles involves an analysis as to how the 'others' and not only the privileged can benefit from a Derridean notion of the ontological and metaphysical presence of English language educators. There is an interrelationship between the privileged and the marginalized. Some educators choose to only work with the marginalized, indigent students, and communities because of their convictions and values. This paper argues for an awareness of the interrelationships between and among the dualistic opposites as a first step. Teach the status quo but, at the same time, bring into their awareness and commit to actionable programs for the marginalized with the participation of privileged students. For example, there are educational initiatives that allow students to interact online with students from other countries or through exchange programs to promote English language skills, cross-cultural communication, and awareness of different cultures. Instead, educators can look at their communities or municipality to bridge social gaps and allow students of different social strata to interact and practice their English with each other.

Similarly, educators who work with more deprived and marginalized groups and communities need not be resentful or indifferent towards the status quo. They can reach out and partner with them. As a new consciousness, educators who value deconstruction bring together a sense of complementarity to what may seem as dualistic opposites.

In so doing, educators design, implement and manage innovative English learning programs. At the surface level, it might seem like the usual English language learning. Much more profound is a consciousness inclined towards and committed to social advocacy and social responsibility. The dualistic opposites, privileged, and underprivileged work together in improving each other's English proficiency. The dynamics between these two groups facilitated, students mentored, and the quality of educational outcomes assessed and evaluated just like any project-based or problembased learning task.

The end hope is for the interaction between the privileged and underprivileged students to bear fruit, such as better awareness and a call-to-action in response to global issues of the 21 st century. The third step involves the active recruitment of willing English language learners to become social advocates themselves who look out for the English language learning needs and welfare of marginalized student populations within their university, community, or elsewhere. This group can work directly as part of the community service efforts of higher education professionals. They can also work independently as a special-interest student club mentored by an advisor. Teachers innovate through the development of learning activities and programs that aim not only for edutainment but both social advocacy and social responsibility.

Tiangco, J. A. N. Z. (2020). Deconstructing the evolving roles of English language educators in the 21 st century. International Journal of Linguistics, Literature and Culture, 6(4), 49-61. https://doi.org/10.21744/ijllc.v6n4.905 


\section{Conclusion}

Higher education should never lose sight of its leadership role as an institution that promotes and strengthens the development of social responsibility programs (UNESCO 1998a, UNESCO 1998b). It would be fallible to think that tasks related to University Social Responsibility (USR) are only for administrators or specially designated social responsibility offices on campus (Gómez, Pujols, Alvarado, \& Vargas, 2018). To deconstruct the evolving roles of English language educators is to be aware and responsive to the needed social advocacy, activism, and social responsibility called for given the problems and issues haunting the 21 st century. The United Nations General Assembly (2015) launched Transforming our World: The 2030 Agenda for Sustainable Development. Outlined in the agenda were 17 sustainable development goals and targets that have become a rallying point for making the world a better place for everyone. Pedersen (2018) considers sustainable development goals as humanity's gift to the world and one another.

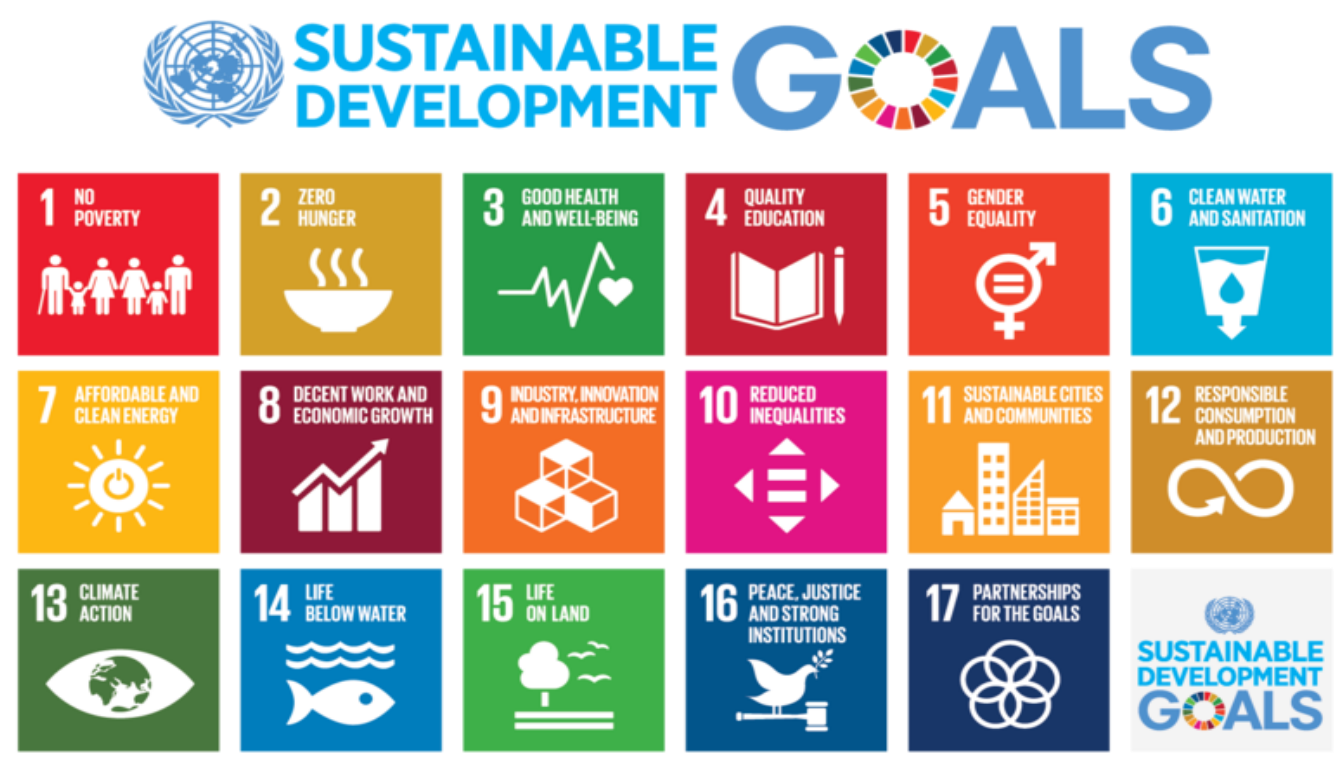

Figure 1. United Nations Sustainable Development Goals (UNSDGs)

Each of the UNSDGs is a starting point for any social advocacy program. If the English language is indeed the global language of success, then English language educators are challenged with the role of changing the world through the impact they can have on English language learners. English teachers are in a unique position to bridge communities of learners. It might be the worst of times, but it can also be the best of times. At the same rate that the English fever became pandemic in the past decades, so can the season of hope be ushered in out of wintery despair. The present is the best time for English language educators to accept their role in the shared mission to make the world a better place for everyone. This period can be their gift to generations of students. English language educators' call-to-action is an advocacy and active participation in University Social Responsibility (USR).

\section{Conflict of interest statement}

The author declares that he has no competing interests.

\section{Statement of authorship}

The author is responsible for the conception and writing of this position paper and has approved the final article.

\section{Acknowledgments}

This work was supported by the Conference Fund provided by Shu-Te University, Taiwan. 


\section{References}

Adamson, B. (2004). China's English: A history of English in Chinese education (Vol. 1). Hong Kong University Press.

AL-Khalil, E. A. (2015, April). The Role of English in Present Day Higher Education. In $B O O K$ of PROCEEDINGS (p. 172).

Archana, S., \& Rani, K. U. (2017). Role of a teacher in English language teaching (ELT). International Journal of Educational Science and Research (IJESR), 7(1), 1-4.

Bolton, K. (2008). English in Asia, Asian Englishes, and the issue of proficiency. English Today, 24(2), 3-12. https://doi.org/10.1017/S026607840800014X

Bolton, K., \& Graddol, D. (2012). English in China today: The current popularity of English in China is unprecedented, and has been fuelled by the recent political and social development of Chinese society. English Today, 28(3), 3-9. https://doi.org/10.1017/S0266078412000223

Blanchard, J.M. (2007). China, multinational corporations, and globalization: Beijing and Microsoft battle over the opening of China's gates. Asian Perspective, 31(3), 67-102.

Blanchard, J. M. F. (2007). China, multinational corporations, and globalization: Beijing and Microsoft battle over the opening of China's gates. Asian perspective, 67-102.

Causadias, J. M., \& Korous, K. M. (2019). Racial discrimination in the United States: a national health crisis that demands a national health solution. Journal of Adolescent Health,64(2), 147-148. https://doi.org/10.1016/j.jadohealth.2018.11.001

Chang, W. C. (2007). On English education of pre-school and post-school. Secondary Education, 58(4), $190-215$.

Chang, Y. F. (2008). Parents' attitudes toward the English education policy in Taiwan. Asia Pacific Education Review, 9(4), 423-435. https://doi.org/10.1007/BF03025660

Chen, S. (2003). The spread of English in Taiwan: Changing uses and shifting attitudes. Crane Publishing Company.

Choudhury, A. S. (2011). Classroom roles of English language teachers: The traditional and the innovative. Contemporary Online Language Education Journal, 1(1), 33-40.

Chzhen, Y., Gromada, A., Rees, G., Cuesta, J., \& Bruckauf, Z. (2018). An Unfair Start: Inequality in Children's Education in Rich Countries (No. inreca995).

Coleman, H. (2010). The English language in development. A paper commissioned by the British Council. Retrieved on Dec, 9, 2014.

Crowley, S. (1989). A Teacher's Introduction to Deconstruction. National Council of Teachers of English, 1111 Kenyon Rd., Urbana, IL 61801 (Stock No. 50144-3020, \$5.95 member, \$7.50 nonmember).

Education First (2019). EF English Proficiency Index: A ranking of 100 countries and regions by English skills. Education First. Retrieved from https://www.ef.com/wwen/epi/

Ellis, R. (1980). Classroom interaction and its relation to second language learning. RELC Journal, 11(2), 29-48. https://doi.org/10.1177\%2F003368828001100203

Ellis, R. (Ed.). (1987). Second language acquisition in context. Englewood Cliffs, NJ: Prentice-Hall International.

Ellis, R. (1997). SLA Research and Language Teaching. Oxford University Press, 198 Madison Avenue, New York, NY 10016-4314.

Ellis, R. (1999). Learning a second language through interaction (Vol. 17). John Benjamins Publishing.

Feng, A. (2005). Bilingualism for the minor or the major? An evaluative analysis of parallel conceptions in China. International Journal of Bilingual Education and Bilingualism, 8(6), 529-551. https://doi.org/10.1080/13670050508669067

Feng, A. (Ed.). (2011). English language education across greater China (Vol. 80). Multilingual Matters.

Gómez, L., Pujols, A., Alvarado, Y., \& Vargas, L. (2018). Social responsibility in higher educational institutions: An exploratory study. In The Goals of Sustainable Development (pp. 215-230). Springer, Singapore. https://doi.org/10.1007/978-981-10-5047-3_13

Hock, H. H. (2019). English in South Asia: Lessons and parallels. World Englishes, 38(1-2), 105-113. https://doi.org/10.1111/weng.12365

Ja, R. (2017). English Teachers' Roles in Promoting Learners' Learning Autonomy in EFL Class of Public Senior High Schools of ENDE Regency in Academic Year 2016/2017. Journal of Education and Human Development, 6(2), 105-112.

Jayadeva, S. (2019). English-medium: schooling, social mobility, and inequality in Bangalore, India. Anthropology \& Education Quarterly, 50(2), 151-169. https://doi.org/10.1111/aeq.12287

Tiangco, J. A. N. Z. (2020). Deconstructing the evolving roles of English language educators in the 21 st century. International Journal of Linguistics, Literature and Culture, 6(4), 49-61. https://doi.org/10.21744/ijllc.v6n4.905 
Johnson, A. (2009). The rise of English: The language of globalization in China and the European Union. Macalester International, 22(1), 12.

Joseph, N. (2017). The promises of deconstructing and disrupting for critical transformation. In

W.M. Smith, B.R. Lawler, J. Bowers, \& L. Augustyn (Eds.), Proceedings of the Sixth Annual Mathematics Teacher Education Partnership Conference (pp. 155-158). Washington, DC: Association of Public and Land-grant Universities.

Kachru, B.B. (1982). The oth 1er tongue: English across cultures. Urbana, IL: University of Illinois Press.

Kachru, B. B. (1983). The indianization of English: the English language in India. Oxford University Press.

Kachru, B. B., Kachru, Y., \& Nelson, C. L. (Eds.). (2006). The handbook of world Englishes (p. 446). Malden, MA: Blackwell.

Kachru, B. (2015). Collected Works of Braj B. Kachru (Vol. 1). Bloomsbury Publishing.

Bok-Rae, K. (2015). The English fever in South Korea: Focusing on the problem of early English education. Journal of Education \& Social Policy, 2(2), 1-8.

Kirkpatrick, A., Subhan, S., \& Walkinshaw, I. (2016). English as a lingua franca in East and Southeast Asia: Implications for diplomatic and intercultural communication. English for diplomatic purposes, 7593.

Krashen, S. (2003). English: The world's second language. In The Proceeding of Twelfth International Symposium on English Teaching (pp. 100-108).

Kung, F. W. (2018). Exploring the SSCI Phenomenon within the Publish or Perish Principle for Non-Native EnglishSpeaking ELT Professionals. TESL-EJ, 22(2), n2.

Lin, W.C., \& Bayram, M. (2016). New approaches to English language and education in Taiwan - Cultural and intercultural perspectives. Taipei: Tung Hua Book Co., Ltd.

Lin, M.C.Y., \& Wong, P. (2016). Recapturing the Taiwan miracle: Diversifying the economy through innovation and collaboration. Singapore: Asia Center Milken Institute.

Liu, L. (2002). Studying English: A national obsession. Retrieved December, 20, 2003.

Lippmann, S., Bulanda, R. E., \& Wagenaar, T. C. (2009). Student entitlement: Issues and strategies for confronting entitlement in the classroom and beyond. College Teaching, 57(4), 197-204. https://doi.org/10.1080/87567550903218596

Lythcott-Haims, J. (2015). How to raise an adult: Break free of the overparenting trap and prepare your kid for success. Henry Holt and Company.

Mart, C. T. (2013). A passionate teacher: Teacher commitment and dedication to student learning. International Journal of Academic Research in Progressive Education and Development, 2(1), 437-442.

Cumming, B., \& Matsumoto, M. (2018). Japanese high school and university students learning English: Differences in their perceptions of teachers as motivators. The Asian Journal of Applied Linguistics, 5(2), 217-229.

McCormick, C. (2017). The link between English and economics. World Economic Forum. Retrieved from https://www.weforum.org/agenda/2017/03/the-link-between-english-and-economics

Meltzer, J. (2014). Taiwans Economic Opportunities And Challenges. East Asia Policy Paper, Center for East Asia Policy Studies, Brookings.

Miller, S. D. (2018). Xenophobia toward refugees and other forced migrants.

National Development Council. (2018). Blueprint for developing Taiwan into a bilingual nation by 2030. Retrieved from

https://bilingual.ndc.gov.tw/sites/bl3/files/news_event_docs/blueprint_for_developing_taiwan_into_a_bilingual_ nation_by_2030.pdf

Chinh, N. D., Quynh, T. H., \& Ha, N. T. (2014). Inequality of access to English language learning in primary education in Vietnam: A case study. In Equality in education (pp. 139-153). Brill Sense.

Nunan, D. (1999). Second Language Teaching \& Learning. Heinle \& Heinle Publishers, 7625 Empire Dr., Florence, KY 41042-2978.

Nunan, D., \& Lamb, C. (1996). The Self-Directed Teacher. Managing the Learning Process Text.

OECD, P. (2019). Results (Volume I): What Students Know and Can Do; PISA.

Oladejo, J. (2006). Parents' attitudes towards bilingual education policy in Taiwan. Bilingual Research Journal, 30(1), 147-170. https://doi.org/10.1080/15235882.2006.10162870

Pedersen, C. S. (2018). The UN Sustainable Development Goals (SDGs) are a great gift to business!. Procedia CIRP, 69, 21-24. https://doi.org/10.1016/j.procir.2018.01.003

Phillipson, R. (2001). English for Globalisation or for the World's People?. International review of education, 47(34), 185-200. https://doi.org/10.1023/A:1017937322957 
Rowe, E., \& Perry, L. B. (2020). Inequalities in the private funding of public schools: parent financial contributions and school socioeconomic status. Journal of Educational Administration and History, 52(1), $42-59$. https://doi.org/10.1080/00220620.2019.1689234

Segrist, D., Bartels, L. K., \& Nordstrom, C. R. (2018). "But Everyone Else is Doing It:” A Social Norms Perspective on Classroom Incivility. College Teaching, 66(4), 181-186. https://doi.org/10.1080/87567555.2018.1482858

Schmid, R. (2018). Pockets of excellence: Teacher beliefs and behaviors that lead to high student achievement at low achieving schools. SAGE Open, 8(3), 2158244018797238. https://doi.org/10.1177\%2F2158244018797238

Smith, O. (2017). Mapped: Where to go if you can't be bothered to learn the language. The Telegraph.

The World Factbook (2020). China. Washington, DC: Central Intelligence Agency. Retrieved from https://www.cia.gov/library/publications/resources/the-world-factbook/index.html

UNESCO. (1998). Autonomía, responsabilidad social y libertad académica. In VII Conferencia Mundial de Educación ED.98/CONF.202/CLD.49. Paris, Francia. Retrieved from https://unesdoc.unesco.org/ark:/48223/pf0000116345_spa

UNESCO. (1998). Declaración Mundial sobre la Educación Superior en el Siglo XXI: Visión y Acción. In Conferencia Mundial Sobre la Educación Superior ED.98/CONF.202/3. París, Francia. Retrieved from https://unesdoc.unesco.org/ark:/48223/pf0000113878_spa

General, A. (2015). Transforming our world: The 2030 agenda for sustainable development. UN.

Wang, F., Wu, D., \& Ma, Y. (2018). EFL students' burnout in English learning: A case study of Chinese middle school students. Asian Social Science, 14(4), 38-45.

Wei, R., \& Su, J. (2012). The statistics of English in China: An analysis of the best available data from government sources. English Today, 28(3), 10-14. https://doi.org/10.1017/S0266078412000235

Wong, L. T., \& Jhaveri, A. D. (2015). English Language Education in a Global World: Practices, Issues and Challenges. Nova Science Publishers, Inc..

Yasmin, F., \& Islam, M. (2018). Academic Roles of English Language Teachers: A Study of the Perceptions of Pakistani Teachers and Students. Journal of Foreign Languages, 6(1), 13-24.

Zhou, M., \& Sun, H. (Eds.). (2006). Language policy in the People's Republic of China: Theory and practice since 1949 (Vol. 4). Springer Science \& Business Media.

Tiangco, J. A. N. Z. (2020). Deconstructing the evolving roles of English language educators in the 21 st century. International Journal of Linguistics, Literature and Culture, 6(4), 49-61. https://doi.org/10.21744/ijllc.v6n4.905 